\title{
IS THE WAIST/HEIGHT RATIO A BETTER PARAMETER THAN BMI IN DETERMINING THE CARDIOMETABOLIC RISK PROFILE OF OBESE PEOPLE?
}

\author{
A razão cintura/estatura é melhor parâmetro que o IMC na determinação do perfil de risco cardiometabólico \\ dos obesos?
}

\author{
Andressa Bressan MALAFAIA ${ }^{1 \oplus}$, Paulo Afonso Nunes NASSIF ${ }^{1,2,3}{ }^{\circ}$, Ricardo Wallace das Chagas LUCAS $^{3 \oplus}$, \\ Rodrigo Ferreira GARCIA ${ }^{2,3}{ }^{\oplus}$, José Guilherme Agner RIBEIRO ${ }^{1 \oplus}$, Laura Brandão DE PROENÇA ${ }^{1 \oplus}$, Maria \\ Eduarda MATTOS ${ }^{1 \oplus}$, Bruno Luiz ARIEDE ${ }^{1 \oplus}$
}

\begin{abstract}
Background: The increased prevalence of obesity has led to a significant increase in the occurrence of metabolic syndrome, a recognized risk factor for increased morbidity and mortality from cardiovascular diseases. Hyperglycemia or type 2 diabetes mellitus, dyslipidemia and arterial hypertension are its main components. Since 2015, international guidelines have recognized the benefits of bariatric surgery in each isolated factor of this syndrome. Aim: To evaluate the impact of Roux-en-Y gastric bypass in this syndrome comparing pre- and postoperative periods with laboratory analysis and to compare waist/height ratio and $\mathrm{BMI}$ in relation to the determination of the cardiometabolic risk profile. Methods: A retrospective study was carried out, selecting 80 patients undergoing Roux-en-Y gastric bypass. Total cholesterol, HDL, LDL, triglycerides, fasting glucose, glycated hemoglobin, insulin, body mass index (BMI), vitamin D, vitamin B12, waist circumference and waist/height ratio in three periods were analyzed: the preoperative period from 1 to 6 months, postoperative from 1 to 6 months and postoperative from 1 to 2 years. Results: There was an improvement in all parameters of the clinical analyses. The preoperative BMI had a mean value of 39.8, in the preoperative period from 1 to 6 months, the values dropped to 33.2 and in the postoperative period of 1 year, the mean was 26. The perimeter mean values of 118.5 preoperatively, 105.2 postoperatively from 1 to 6 months and 90.3 postoperatively from 1 to 2 years. Waist/height ratio was $0.73,0.65$ and 0.56 in pre, post 1 to 6 months and 1 to 2 years respectively. Conclusion: Roux-en-Y gastric bypass improves metabolic syndrome and waist-to-height ratio is superior to BMl in the assessment of the cardiometabolic risk profile.
\end{abstract}

HEADINGS - Obesity. Metabolic Syndrome. Diabetes Mellitus, type 2. Anastomosis, Roux-en-Y.

RESUMO - Racional: O aumento da prevalência da obesidade levou ao aumento significativo da ocorrência de síndrome metabólica, fator de risco reconhecido para aumento da morbimortalidade por doenças cardiovasculares. A hiperglicemia ou diabetes mellitus do tipo 2, dislipidemia e hipertensão arterial são seus principais componentes. Desde 2015, diretrizes internacionais reconheceram os benefícios da cirurgia bariátrica em cada fator isolado desta síndrome. Objetivos: Avaliar o impacto do bypass gástrico em Y-de-Roux nesta síndrome comparando períodos pré e pós-operatório com análise laboratorial, e comparar a razão cintura/estatura e o IMC em relação a determinação do perfil de risco cardiometabólico. Métodos: Realizou-se um estudo retrospectivo com base prospectiva selecionando 80 pacientes submetidos à bypass gástrico em Y-de-Roux. Foram analisados o colesterol total, HDL, LDL, triglicerídeos, glicemia de jejum, hemoglobina glicada, insulina, índice de massa corpórea (IMC), vitamina D, vitamina B12, perímetro abdominal e relação cintura/estatura em três períodos: o pré-operatório de 1 a 6 meses, pós-operatório de 1 a 6 meses e pós-operatório de 1 a 2 anos. Resultados: Houve melhora em todos os parâmetros das análises clínicas. O IMC, no pré-operatório, teve a média dos valores de 39,8, no pré-operatório de 1 a 6 meses, os valores caíram para 33,2 e no pós-operatório de 1 ano média foi de 26.0 perímetro abdominal teve média dos valores de 118,5 , no pré-operatório, 105,2 no pós-operatório de 1 a 6 meses e 90,3 no pós-operatório de 1 a 2 anos. A relação cintura/estatura teve 0,73, 0,65 e 0,56 no pré, pós 1 a 6 meses e 1 a 2 anos respectivamente. Conclusão: $O$ bypass gástrico em Y-de-Roux melhora a síndrome metabólica e a relação cintura/estatura é superior ao IMC na avaliação do perfil do risco cardiometabólico.

DESCRITORES - Obesidade. Síndrome Metabólica. Diabete Melito tipo 2. Anastomose em Y-de-Roux.

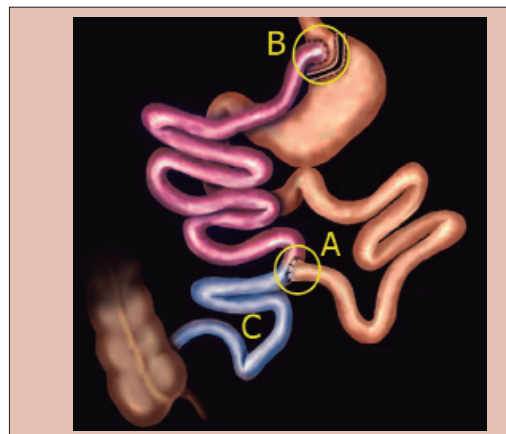

RYGB demonstration: A) Jejunojejunal anastomosis $120 \mathrm{~cm}$ from the duodenal flexure (biliopancreatic loop - in brown); B) Gastrojejunal anastomosis 120 $\mathrm{cm}$ from the jejunojejunal anastomosis (food loop - in purple); C) Common handle (in blue).

\section{Central message}

The increase in the global prevalence of metabolic diseases is inexplicable when considering only environmental or genetic factors. There is a need to explore the possible roles of epigenetic factors. Despite gaps in our knowledge, evidence suggests that measuring waist circumference improves patient management and should be an integral part of a preoperative protocol to improve patient care and health.

\begin{tabular}{|l|}
\hline Perspective \\
Much progress has been made in this interdisciplinary \\
field in recent years, with many studies investigating \\
various aspects of the metabolic syndrome and \\
its associated epigenetic changes. Metabolically \\
healthy obesity is not a stable or reliable indicator \\
of future risk for cardiovascular disease. The waist \\
circumference threshold for a given BMI category \\
at different ages, by gender and by ethnicity will \\
require further investigation. Evidence suggests that \\
measuring waist circumference improves patient \\
management and should be an integral part of a \\
pre-and postoperative protocol.
\end{tabular}

Correspondence:

Paulo Afonso Nunes Nassif

E-mail: paulonassif@terra.com.br
Financial source: This study was financed in part by the Coordenação de Aperfeiçoamento de Pessoal de Nível Superior - Brasil (CAPES) Finance Code 001

Conflict of interest: none

Received for publication: 09/12/2020

Accepted for publication: 23/03/2021 
INTRODUCTION

$\mathrm{T}$ he increase in the obese population in the world is exponential, it is estimated that $30 \%$ of people are overweight or obese, significantly increasing morbidity and mortality from cardiovascular, oncological, endocrine and liver diseases, among others ${ }^{11,38,41}$.

Obesity, particularly abdominal obesity, is associated with resistance to the effects of insulin on the peripheral use of glucose and fatty acids, one of the components of the physiopathogenesis of type 2 diabetes mellitus, hyperinsulinemia and the increase in adipocyte cytokines. All these factors significantly increase cardiovascular risk, either alone or in combination. In addition to type 2 diabetes mellitus, other obesity-associated comorbidities, such as hypertension and dyslipidemia, are also direct risk factors for the development of cardiovascular disease. In this context, in 2014, Samson et al..$^{40}$ called the concomitance of these comorbidities as syndrome $X$, currently known as metabolic syndrome (MS) $)^{9,40}$.

MS is characterized by abdominal perimeter greater than or equal to $102 \mathrm{~cm}$ in men and $88 \mathrm{~cm}$ in women; fasting glucose greater than $100 \mathrm{mg} / \mathrm{dl}$; triglycerides above 150 $\mathrm{mg} / \mathrm{dl} ; \mathrm{HDL}$ cholesterol less than $40 \mathrm{mg} / \mathrm{dl}$ in men and less than $50 \mathrm{mg} / \mathrm{dl}$ in women; and arterial hypertension (>130 $\mathrm{mmHg},>85 \mathrm{mmHg}$ ). It is believed that obesity and insulin resistance are the main factors for the development of this syndrome ${ }^{17}$.

Due to the need for a more effective treatment, the term "metabolic surgery" emerged from the recognition of the metabolic effects of bariatric surgery, in addition to weight loss. Currently, the most performed procedures are Roux-en-Y gastric bypass (RYGB) and sleeve gastrectomy. Most patients with MS obtain significant improvements with bariatric surgery ${ }^{5}$.

A recent review by Hwuang ${ }^{17}$ exploring ideal waistto-height ratios and subsequent comments $\mathrm{s}^{6,32}$ concluded that height-adjusted waist circumference (known as waist circumference index) is superior to BMI in its association with body fat. This conclusion contrasts with the recent IAC and ICCR (International Atherosclerosis Society and International Chair On Cardiometabolic Risk) Consensus report on visceral obesity, which argued that waist circumference thresholds alone are adequate for the assessment of abdominal obesity in clinical practice ${ }^{3,36}$.

There is an unmet need to promote consistent and universal public health message that visceral/central/abdominal obesity is associated with adverse health outcomes ${ }^{32}$. The authors of this research have used the waist-to-height ratio (WHtR) for almost 25 years as an adjunct indicator to BMI. It is a better predictor for central obesity, and superior for cardiovascular risk factors ${ }^{2}$. But the waist circumference index is superior to the WHtR in this respect.

The National Institute of Excellence in Health and Care - NICE - recognized the value of WHtR as an indicator of initial risk to health. We use recent data from the UK to explore whether the WHtR-based classification identifies more cardiometabolic risk than the 'matrix' based on BMI and waist circumference currently used for screening. Data from the Health Survey for England of 4112 obese people were used to identify cardiometabolic risk, as indicated by elevated glycated $\mathrm{Hb}$, dyslipidemia, and hypertension. HbA1c, total/HDL cholesterol and systolic blood pressure were more strongly associated with WHtR than 'matrix'. The WHtR 0.5 cut in the initial screening translates to a simple message: the waist should be less than half the height. This allows individuals to be aware of their health risks ${ }^{3}$.
WHtR is a simple anthropometric predictor for central body fat and is easy to use from a health education perspective. $\mathrm{WH} \mathrm{tR}>0.5$ was proposed as the first level of health risk. $\mathrm{BMI}$ is the most used to define weight status in relation to height, and its units are in $\mathrm{kg} / \mathrm{m}^{2}{ }^{36}$. Despite the strong correlation between body fat and BMI, it cannot distinguish between lean mass and fat mass 15,35 . Thus, it is important to analyze each factor that makes up MS individually, in order to verify the real impact of bariatric surgery on each comorbidity.

Thus, this study aimed to evaluate the impact of Rouxen-Y gastric bypass comparing the pre- and postoperative period of 1 to 6 months, and the postoperative period of 1 to 2 years in MS and compare waist ratio/height and BMI in relation to the determination of the cardiometabolic risk profile.

\section{METHOD}

Data were collected from the prospective file of electronic medical records of Instituto Paulo Nassif, in Curitiba, PR, from January 2017 to December 2019. This work was approved by the Research Ethics Committee of Mackenzie Evangelical Faculty of Paraná, Curitiba, PR, Brazil, under number 4,324 .990.

\section{Sample}

Eighty patients who participated in a one-year multidisciplinary bariatric surgery preparation program were evaluated.

The inclusion criteria were: 1) patients who underwent bariatric surgery by RYGB and who had laboratory measurements from three different periods; 2) standard collection 1 to 6 months before the operation; 3 ) standard collection from 1 to 6 months postoperatively; 4) standard collection from 1 to 2 years postoperatively.

The only exclusion criterion was being under 18 years old and over 65 years old.

\section{Variables analyzed}

The following were researched: 1) clinical analyzes were on fasting glucose, serum insulin, glycated hemoglobin, total cholesterol, total triglycerides, HDL and LDL; 2) BMI of each patient before and after the operation in the same periods; 3 ) abdominal perimeter measured with an inextensible measuring tape in the smallest curvature located between the ribs and the iliac crest, at the normal expiratory moment; 4) waist/ height ratio determined by dividing the smallest curvature located between the ribs and the iliac crest, at the normal expiratory moment, by height, measured in centimeters.

\section{Operative technique}

The RYGB consisted of building a small gastric reservoir (stomach with about $20 \mathrm{ml}$ ) performing two anastomoses, the gastrojejunal and the jejunojejunal (Figure 1). The rest of the stomach and the diverted intestine were not removed from the body, just excluded from the path taken by food and digestive enzymes. This deviated part anastomoses $120 \mathrm{~cm}$ from the duodenojejunal flexure with the jejunum, characterizing the biliopancreatic loop (Figure 1A). From the jejunojejunal anastomosis to the small gastric reservoir, also $120 \mathrm{~cm}$ long, characterizes the alimentary loop (Figure 1B). From the jejunojejunal anastomosis to the ileocecal valve, we have the common loop (Figure 1C). 


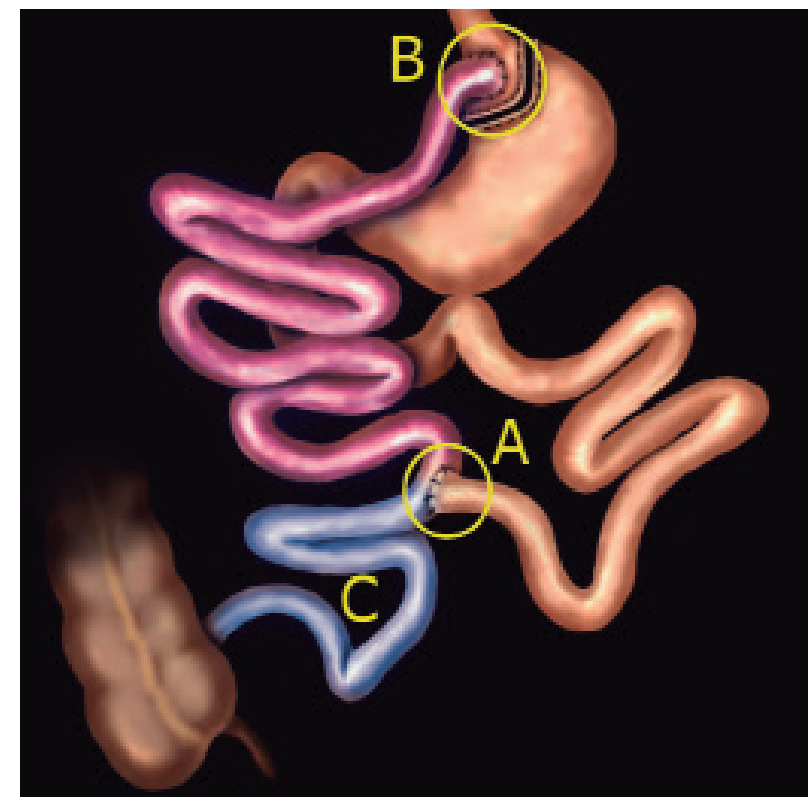

FIGURE 1 - RYGB demonstration: A) Jejunojejunal anastomosis 120 $\mathrm{cm}$ from the duodenal flexure (biliopancreatic loop - in brown); B) Gastrojejunal anastomosis $120 \mathrm{~cm}$ from the jejunojejunal anastomosis (food loop - in purple); C) Common handle (in blue).

\section{Statistical analysis}

Results of quantitative variables were described as mean standard deviation, median, minimum and maximum. Categorical variables were described by frequency and percentage. To assess the correlation between two quantitative variables, Pearson's linear correlation coefficients were estimated. To compare the evaluations before, after 1 to 6 months and after 1 to 2 years, in relation to quantitative variables, the analysis of variance model (ANOVA) with repeated measures and the Bonferroni test were used for comparisons of the two evaluations to two. Regarding categorical variables, comparisons were made using the binomial test. For the comparison of two groups, in relation to quantitative variables, the Student t test for independent samples was used. The condition of normality of continuous variables was assessed using the Kolmogorov-Smirnov test. Data from variables that did not meet this condition were submitted to a logarithmic transformation. Values of $p<0.05$ indicated statistical significance. For multiple comparisons using the binomial test, $p$ values were corrected by Bonferroni. Data were analyzed using the computer program Stata/SE v.14.1. StataCorpLP, USA.

\section{RESULTS}

\section{Descriptive statistics}

The analysis presented below was performed based on data from 80 patients undergoing RYGB.

TABLE 1 - Descriptive analysis

\begin{tabular}{|c|c|c|}
\hline Variable & Classif & Result* \\
\hline Age (years) & & $41.5 \pm 10.4(20.5-66)$ \\
\hline Gender & Female & $69(86.3 \%)$ \\
\hline DM2 (pre) & Male & $11(13.8 \%)$ \\
\hline Dyslipidemia (pre) & Yes & $61(76.3 \%)$ \\
\hline SAH (pre) & No & $19(23.8 \%)$ \\
\hline Yes & No & $38(47.5 \%)$ \\
\hline (pescribed by mean \pm standard deviation (minimum & - maximum) or frequency \\
\hline
\end{tabular}

Evaluation of surgical results on clinical variables Categorical variables

For each of them, the null hypothesis that there was no difference between the distributions in the pre-assessment and in the assessment of 1 to 6 months, vs. the alternative hypothesis that there was. This same comparative analysis was performed for the pre, 1 to 2 years, 1 to 6 months, and 1 to 2 years of evaluation moments. Table 2 presents descriptive statistics of the variables at each time of evaluation and $p$ values of the statistical tests.

TABLE 2 - Descriptive statistics of the variables DM2, systemic arterial hypertension, and dyslipidemia at each evaluation moment

\begin{tabular}{|c|c|c|c|c|c|c|c|}
\hline \multirow[b]{2}{*}{ Variable } & \multirow[b]{2}{*}{ Classif } & \multirow[b]{2}{*}{ Pre } & \multirow[b]{2}{*}{$\begin{array}{l}\text { Post } \\
1 \text { to } 6 \mathrm{~m}\end{array}$} & \multirow[b]{2}{*}{$\begin{array}{l}\text { Post } \\
1 \text { to } 2 y\end{array}$} & \multicolumn{3}{|c|}{$p^{*}$} \\
\hline & & & & & $\begin{array}{c}\text { Pre } x \\
\text { post } \\
1 \text { to } 6 \mathrm{~m}\end{array}$ & $\begin{array}{c}\text { Pre } x \\
\text { post } \\
1 \text { to } 2 y\end{array}$ & $\begin{array}{l}\text { Post } 1 \text { to } 6 \mathrm{~m} \\
\mathrm{x} \text { post } 1 \text { to } 2 \mathrm{y}\end{array}$ \\
\hline \multirow{2}{*}{ DM2 } & No & $\begin{array}{c}61 \\
(76.3 \%)\end{array}$ & $\begin{array}{c}78 \\
(97.5 \%)\end{array}$ & $\begin{array}{c}78 \\
(97.5 \%)\end{array}$ & & & \\
\hline & Yes & $\begin{array}{c}19 \\
(23.8 \%)\end{array}$ & $\begin{array}{c}2 \\
(2.5 \%)\end{array}$ & $\begin{array}{c}2 \\
(2.5 \%)\end{array}$ & $<0.001$ & $<0.001$ & 1 \\
\hline \multirow{2}{*}{ SAH } & No & $\begin{array}{c}46 \\
(57.5 \%)\end{array}$ & $\begin{array}{c}73 \\
(91.3 \%)\end{array}$ & $\begin{array}{c}75 \\
(93.8 \%)\end{array}$ & & & \\
\hline & Yes & $\begin{array}{c}34 \\
(42.5 \%)\end{array}$ & $\begin{array}{c}7 \\
(8.8 \%)\end{array}$ & $\begin{array}{c}5 \\
(6.3 \%)\end{array}$ & $<0.001$ & $<0.001$ & 1 \\
\hline \multirow{2}{*}{ Dyslipidemia } & No & $\begin{array}{c}38 \\
(47.5 \%)\end{array}$ & $\begin{array}{c}78 \\
(97.5 \%)\end{array}$ & $\begin{array}{c}78 \\
(97.5 \%)\end{array}$ & & & \\
\hline & Yes & $\begin{array}{c}42 \\
(52.5 \%)\end{array}$ & $\begin{array}{c}2 \\
(2.5 \%)\end{array}$ & $\begin{array}{c}2 \\
(2.5 \%)\end{array}$ & $<0.001$ & $<0.001$ & 1 \\
\hline
\end{tabular}

*Binomial test ( $p$ values corrected by Bonferroni); $p<0.05 ; \mathrm{SAH}=$ systemic arterial hypertension

\section{Quantitative variables}

For each of these variables that met the condition of normality, the null hypothesis was tested that the means in the three assessments (pre, post 1-6 m and post 1-2 y) were equal, vs. the alternative hypothesis that the means were not. In the case of rejection of the null hypothesis, the evaluation moments were compared two by two.

For each of the quantitative variables that did not meet the normality condition, the null hypothesis that the results in the three evaluations (pre, post 1-6 m and post 1-2 y) were equal, vs. the alternative hypothesis that they weren't. In the case of rejection of the null hypothesis, the evaluation moments were compared two by two.

Table 3 presents descriptive statistics of the variables at each evaluation moment and $p$ values of the statistical tests.

Assessment of the correlation between $\mathrm{BMI}$ and $\mathrm{WHtR}$

For each of the evaluation moments (pre, post 1 to $6 \mathrm{~m}$ and after 1 to $2 \mathrm{y}$ ) and for the differences between the evaluations, the null hypothesis was tested that the correlation coefficient between $\mathrm{BMI}$ and WHtR was equal to zero (there was no correlation between the two variables) vs. the alternative hypothesis that the correlation coefficient was non-zero (there was correlation). Table 4 shows the values of Pearson's linear correlation coefficients and the $p$ values of the statistical tests.

TABLE 4 - Ratio between waist/height and BMI at each assessment moment

\begin{tabular}{|c|c|c|}
\hline Evaluation & $\begin{array}{c}\text { Correlation coefficient } \\
\text { of Pearson between } \\
\text { relationship WHtR and } \\
\text { BMI }\end{array}$ & $p$ \\
\hline Pre & 0.54 & $<0.001$ \\
\hline Post 1 to $6 \mathrm{~m}$ & 0.37 & 0.001 \\
\hline Post 1 to $2 y \div$ & 0.42 & $<0.001$ \\
\hline Reduction (pre - post 1 to $6 \mathrm{~m}$ ) & 0.12 & 0.294 \\
\hline Reduction (pre - post 1 to $2 \mathrm{y}$ ) & 0.42 & $<0.001$ \\
\hline Reduction (after 1 to $6 \mathrm{~m}$ - after 1 to $2 \mathrm{y}$ ) & 0.32 & 0.004 \\
\hline
\end{tabular}


TABLE 3 - Descriptive statistics of the variables abdominal waist, WHtR, vitamin B12, vitamin D, total cholesterol, HDL, LDL, triglycerides, glycated hemoglobin, insulin, glucose and BMI at each evaluation moment

\begin{tabular}{|c|c|c|c|c|c|c|c|}
\hline \multirow[b]{2}{*}{ Variable } & \multirow[b]{2}{*}{ Evaluation } & \multirow{2}{*}{$\begin{array}{c}\text { Mean } \pm \\
\text { standard deviation }\end{array}$} & \multirow[b]{2}{*}{ Median (min-max) } & \multicolumn{4}{|c|}{$p^{*}$} \\
\hline & & & & $\begin{array}{l}\text { Pre } x \text { post } 1-6 \mathrm{~m} \\
\mathrm{x} \text { pós } 1-2 \mathrm{y}\end{array}$ & $\begin{array}{c}\text { Pre } x \text { post } \\
1-6 \mathrm{~m}\end{array}$ & $\begin{array}{c}\text { Pre } x \text { Post } \\
1-2 y\end{array}$ & $\begin{array}{l}\text { Post } 1-6 \mathrm{~m} \\
\mathrm{x} \text { post } 1-2 \mathrm{y}\end{array}$ \\
\hline \multirow{3}{*}{$\mathrm{AW}(\mathrm{cm})$} & Pre & $118.5 \pm 9.4$ & $119(98-140)$ & & & & \\
\hline & Post 1-6 m & $105.2 \pm 9.9$ & $106(81-126)$ & & & & \\
\hline & Post $1-2 y$ & $90.3 \pm 7.7$ & $90(74-110)$ & $<0.001$ & $<0.001$ & $<0.001$ & $<0.001$ \\
\hline \multirow{3}{*}{ WHtR } & Pre & $0.73 \pm 0.06$ & $0.72(0.61-0.87)$ & & & & \\
\hline & Post 1-6 m & $0.65 \pm 0.07$ & $0.65(0.50-0.80)$ & & & & \\
\hline & Post $1-2 y$ & $0.56 \pm 0.05$ & $0.55(0.45-0.69)$ & $<0.001$ & $<0.001$ & $<0.001$ & $<0.001$ \\
\hline \multirow{3}{*}{ Vitamin B12 } & Pre & $509.8 \pm 276.1$ & $454.5(209-2000)$ & & & & \\
\hline & Post 1-6 m & $693.5 \pm 417.1$ & $591.5(198-2000)$ & & & & \\
\hline & Post $1-2 y$ & $639.6 \pm 388.5$ & $511(192-2000)$ & 0.002 & 0.001 & 0.052 & 0.733 \\
\hline \multirow{3}{*}{ Vitamin D } & Pre & $26.8 \pm 7.2$ & $26.7(10.3-47.5)$ & & & & \\
\hline & Post 1-6 m & $31.8 \pm 9.3$ & $30.1(6.9-64.3)$ & & & & \\
\hline & Post $1-2 y$ & $33.3 \pm 10.8$ & $32(11.3-78.4)$ & $<0.001$ & 0.001 & $<0.001$ & 0.843 \\
\hline \multirow{3}{*}{ Total colesterol } & Pre & $174.6 \pm 34.2$ & $177.5(66-246)$ & & & & \\
\hline & Post 1-6 m & $149.6 \pm 31.8$ & $153(77-217)$ & & & & \\
\hline & Post $1-2 y$ & $150.2 \pm 28.2$ & $147.5(94-227)$ & $<0.001$ & $<0.001$ & $<0.001$ & 1 \\
\hline \multirow{3}{*}{$\mathrm{HDL}$} & Pre & $49.7 \pm 12.1$ & $47.5(21-79)$ & & & & \\
\hline & Post $1-6 \mathrm{~m}$ & $45.6 \pm 12.0$ & $43.5(25-89)$ & & & & \\
\hline & Post $1-2 \mathrm{y}$ & $57.5 \pm 13.1$ & $56(28-89)$ & $<0.001$ & 0.002 & $<0.001$ & $<0.001$ \\
\hline \multirow{3}{*}{ LDL } & Pre & $96.6 \pm 27.5$ & $100.5(43-169)$ & & & & \\
\hline & Post $1-6 \mathrm{~m}$ & $85.5 \pm 27.4$ & $82(41-176)$ & & & & \\
\hline & Post $1-2 y$ & $76.3 \pm 25.9$ & $74.5(30-166)$ & $<0.001$ & $<0.001$ & $<0.001$ & 0.004 \\
\hline \multirow{3}{*}{ Triglycerides } & Pre & $152.6 \pm 68.3$ & $133(50-423)$ & & & & \\
\hline & Post $1-6 \mathrm{~m}$ & $96.1 \pm 34.8$ & $89.5(41-195)$ & & & & \\
\hline & Post $1-2$ y & $82.1 \pm 28.7$ & $79.5(36-179)$ & $<0.001$ & $<0.001$ & $<0.001$ & 0.017 \\
\hline \multirow{3}{*}{ Glycated hemog } & Pre & $6.1 \pm 1.6$ & $5.8(4.8-14.4)$ & & & & \\
\hline & Post $1-6 \mathrm{~m}$ & $5.7 \pm 1.4$ & $5.3(4.3-13.3)$ & & & & \\
\hline & Post $1-2 y$ & $5.6 \pm 1.4$ & $5.3(4.5-13.6)$ & $<0.001$ & $<0.001$ & $<0.001$ & 0.367 \\
\hline \multirow{3}{*}{ Insuline } & Pre & $22.2 \pm 12.4$ & $20(5-71.2)$ & & & & \\
\hline & Post 1-6 m & $8.1 \pm 4.4$ & $7(2-24.4)$ & & & & \\
\hline & Post $1-2 y$ & $6.2 \pm 2.9$ & $5.5(1-16)$ & $<0.001$ & $<0.001$ & $<0.001$ & 0.265 \\
\hline \multirow{3}{*}{ Glucose } & Pre & $102 \pm 25.6$ & $97(67-238)$ & & & & \\
\hline & Post 1-6 m & $90 \pm 16.6$ & $87(65-180)$ & & & & \\
\hline & Post $1-2 y$ & $88.3 \pm 18.3$ & $84(71-185)$ & $<0.001$ & $<0.001$ & $<0.001$ & 0.504 \\
\hline \multirow{3}{*}{$\mathrm{BMI}\left(\mathrm{kg} / \mathrm{m}^{2}\right)$} & Pre & $39.8 \pm 3.8$ & $39.5(31-52.5)$ & & & & \\
\hline & Post 1-6 m & $33.2 \pm 4.3$ & $33.4(23.3-45.2)$ & & & & \\
\hline & Post $1-2 y$ & $26.0 \pm 3.2$ & $25.8(19.6-38)$ & $<0.001$ & $<0.001$ & $<0.001$ & $<0.001$ \\
\hline
\end{tabular}

*ANOVA with repeated measures and Bonferroni test (post-hoc); $\mathrm{p}<0.05 ; \mathrm{AW}=$ abdominal waist; WHtR=waist-to-height ratio; vitamin $\mathrm{B} 12$, glycated hemoglobin and glucose data were submitted to logarithmic transformation

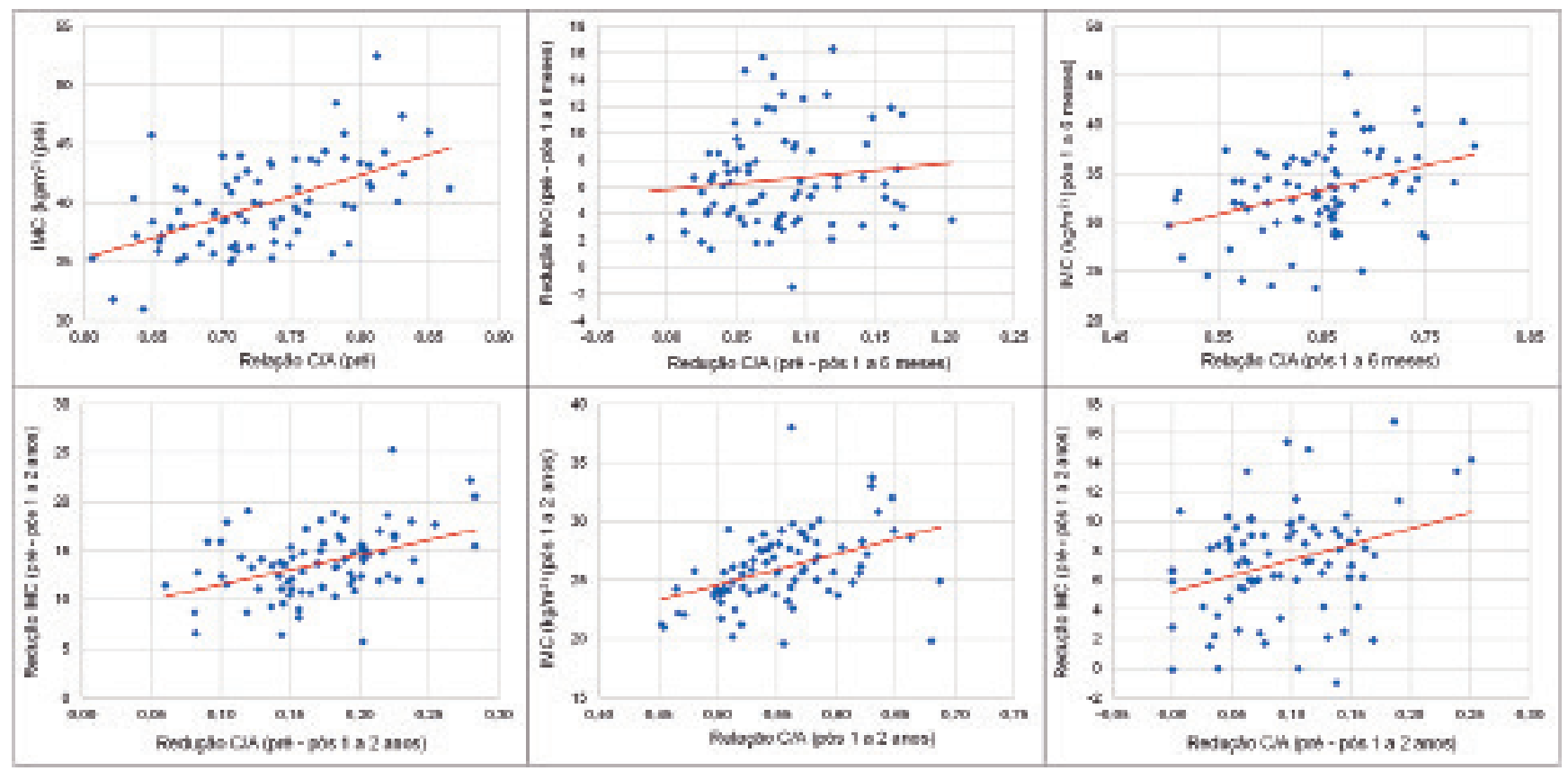

FIGURE 2 - Waist/height ratio (WHtR) and BMI at each assessment time 


\section{cardiometabolic risk}

Assessment of the association between BMI and

For this analysis, two groups were defined according to cardiometabolic risk: group 1 - patients who had cardiometabolic risk in the pre and post 1 to 6 months assessments and stopped having it after 1 to 2 years $(n=8)$; group 2 - patients who had cardiometabolic risk in all assessments (pre, post 1 to $6 \mathrm{~m}$ and post 1 to $2 \mathrm{y}, \mathrm{n}=72$ )

For each moment of BMl assessment and for the reductions between assessments, the null hypothesis that the BMI means were equal in both groups was tested, vs. the alternative hypothesis that the means were different.

Table 5 and Figure 2 show descriptive statistics of the evolutionary graphic BMI according to groups 1 and 2, and the $p$ values of the statistical tests. For reductions, positive values indicate a reduction in $\mathrm{BMl}$ and negative values indicate an increase.

TABLE 5 - Descriptive statistics of BMI according to groups 1 and 2

\begin{tabular}{|c|c|c|c|c|c|}
\hline \multirow[b]{2}{*}{ Evaluation } & \multirow[b]{2}{*}{ Group } & \multirow[b]{2}{*}{$\mathrm{n}$} & \multicolumn{2}{|c|}{ BMI $\left(\mathrm{kg} / \mathrm{m}^{2}\right)$} & \multirow[b]{2}{*}{$p^{*}$} \\
\hline & & & $\begin{array}{l}\text { Mean } \pm \\
\text { standard } \\
\text { deviation }\end{array}$ & $\begin{array}{l}\text { Median } \\
(\text { min-max) }\end{array}$ & \\
\hline \multirow{2}{*}{ Pre } & 1 & 8 & $38.2 \pm 2.7$ & $\begin{array}{c}37.4 \\
(35.3-43.5)\end{array}$ & \\
\hline & 2 & 72 & $40.0 \pm 3.8$ & $\begin{array}{c}39.7 \\
(31-52.5)\end{array}$ & 0.205 \\
\hline \multirow{2}{*}{ Post 1 to $6 \mathrm{~m}$} & 1 & 8 & $30.9 \pm 3.8$ & $\begin{array}{c}31.8 \\
(24.6-36.3)\end{array}$ & \\
\hline & 2 & 72 & $33.5 \pm 4.4$ & $\begin{array}{c}33.7 \\
(23.3-45.2)\end{array}$ & 0.116 \\
\hline \multirow{2}{*}{ Post 1 to $2 y$} & 1 & 8 & $23.0 \pm 1.7$ & $\begin{array}{c}22.9 \\
(21-25.8)\end{array}$ & \\
\hline & 2 & 72 & $26.4 \pm 3.2$ & $\begin{array}{c}26.1 \\
(19.6-38)\end{array}$ & 0.004 \\
\hline \multirow{2}{*}{ Reduction (pre - 1 to 6 m) } & 1 & 8 & $7.26 \pm 3.83$ & $\begin{array}{c}7.45 \\
(1.3-12.6)\end{array}$ & \\
\hline & 2 & 72 & $6.50 \pm 3.67$ & $\begin{array}{c}6.0 \\
(-1.5-16.3)\end{array}$ & 0.578 \\
\hline \multirow{2}{*}{ Reduction (pre - 1 to 2 y) } & 1 & 8 & $15.2 \pm 1.69$ & $\begin{array}{c}15.2 \\
(11.9-17.7)\end{array}$ & \\
\hline & 2 & 72 & $13.6 \pm 3.56$ & $\begin{array}{c}13.4 \\
(5.7-25.3)\end{array}$ & 0.043 \\
\hline \multirow{2}{*}{$\begin{array}{l}\text { Reduction (after } 1 \text { to } 6 \mathrm{~m} \text { - } \\
\text { after } 1 \text { to } 2 \mathrm{y} \text { ) }\end{array}$} & 1 & 8 & $7.91 \pm 3.64$ & $\begin{array}{c}7.4 \\
(2.4-14.2)\end{array}$ & \\
\hline & 2 & 72 & $7.11 \pm 3.65$ & $\begin{array}{c}7.25 \\
(-1-16.8)\end{array}$ & 0.557 \\
\hline
\end{tabular}

*Student's t test for independent samples, $p<0.05$

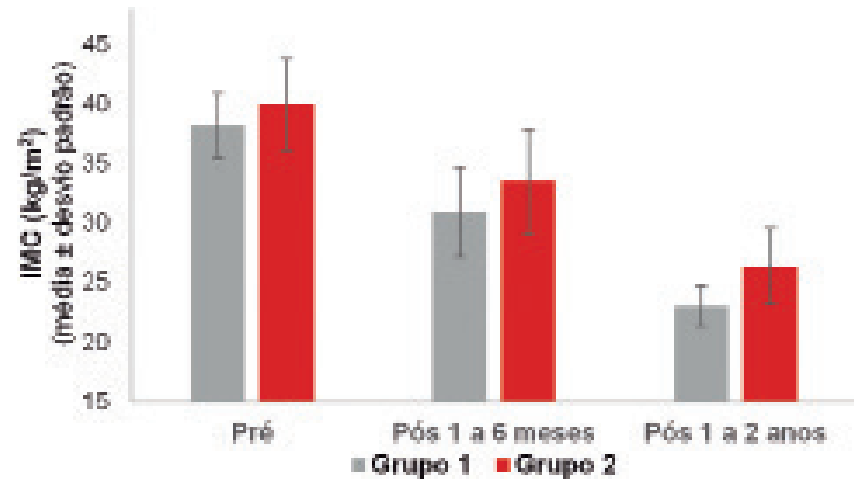

FIGURE 3 - Graph showing the evolution of BMI according to groups 1 and 2

DISCUSSION

The increased prevalence of MS due to the obesity pandemic, secondary to the current sedentary lifestyle associated with poor diet, has been correlated with higher morbidity and mortality from cardiovascular diseases. MS, in addition to harming the quality of life and health of its individual patients, has become a public health problem. This is due to the costly costs applied to the treatment of chronic diseases involved in MS on an individual basis, in addition to the complications brought about by the syndrome $12,13,14$.

In this context, metabolic surgery has been shown to significantly improve some of the MS components, the main ones being $\mathrm{DM} 2$, dyslipidemia and abdominal perimeter. According to the literature, there is a consensus that there is improvement in the laboratory parameters of patients who undergo metabolic surgery, with RYGB being the most performed procedure currently ${ }^{18,34}$.

In addition to clinical and laboratory parameters, a remarkable factor is that the improvement in MS decreases cardiovascular risk. Corroborating other studies $1,6,9,17,31$, this research showed improvement in the variables that contribute to the development of cardiovascular diseases.

Metabolic surgery has been shown to have a great antidiabetogenic effect, which leads to early resolution of the disease picture, even before major weight loss. As proposed by Varaschim et al. (2012) ${ }^{43}$, this fact can be explained by the endocrine effect produced by this procedure. The comparison between the pre- and postoperative periods was significant, while the comparison between the two postoperative periods was not. Similar results were obtained for glycated hemoglobin values, which also decreased when compared pre- and postoperatively.

One of the main factors that contribute to the development of DM2 is insulin resistance, which causes an increase in serum insulin concentration. In this context, metabolic surgery proves to be efficient in decreasing insulin resistance, as the values drop considerably after the procedure. The present study obtained preoperative insulin values averaging 22.2 $\mu \mathrm{IU} / \mathrm{ml}$, in the first postoperative period it was $8.1 \mu \mathrm{lU} / \mathrm{ml}$ and $6.1 \mu \mathrm{IU} / \mathrm{ml}$ in the second - all with significance $(p<0.001)$.

The main risk factor for coronary disease, among the components of MS, is dyslipidemia. It is known that metabolic surgery has a positive influence on improving the lipid profile. As described by Guilbert et al. $(2018)^{17}$ the reduction in triglyceride levels is mainly associated with weight loss, that is, it presents a gradual reduction, a fact that was confirmed by the results of the present study, in which the initial mean was $152.5 \mathrm{mg} / \mathrm{dl}$, the $96 \mathrm{mg} / \mathrm{dl}$ in the first postoperative period and $82.1 \mathrm{mg} / \mathrm{dl}$ in the second $(p<0.001)$. In the analysis of $\mathrm{HDL}$, the results showed an average of $49.6 \mathrm{mg} / \mathrm{dl}$ in the pre, $45.6 \mathrm{mg} / \mathrm{dl}$ in the post 1 to 6 months and in the 1 to 2 years period with an average of $57.5 \mathrm{mg} / \mathrm{dl}$ - all with significance $(p<0.001)$. Guilbert et al. $(2018)^{17}$ also discuss HDL and explain that, unlike triglycerides, HDL goes through two phases, a decline immediately after the operation and then an increase in the first six months, reflecting the gradual qualitative change, with maturation of the particles, accompanied by an increase in its antioxidant potential, favoring its cardiovascular protection properties. For both components, changes in lifestyle after the operation (increased physical activity and type of diet) have a direct impact 22,33.

Elevated LDL levels are an important component in the pathophysiology of atherosclerosis; thus, metabolic surgery to improve LDL levels contributes to lower cardiovascular risk. In this work, LDL values were found with a mean of 96.6 $\mathrm{mg} / \mathrm{dl}$ before the operation, after which the mean dropped to $85.4 \mathrm{mg} / \mathrm{dl}$ at first and then to $76.2 \mathrm{mg} / \mathrm{dl}$ ( $p<0.001 \mathrm{in}$ all analyses). The values found corroborate Nassif et al. $(2009)^{31}$, who also showed a progressive drop in LDL. In the analysis of total cholesterol, the results showed a mean of $174.6 \mathrm{mg} / \mathrm{dl}$ preoperatively, $149.5 \mathrm{mg} / \mathrm{dl}$ and $150.2 \mathrm{mg} / \mathrm{dl}$, respectively, in the first and second postoperative periods. There was significance only in the comparison between pre and postoperative periods $(p<0.001)$. 
$\mathrm{BMI}$ is the parameter used to indicate the surgical treatment of obesity, in addition to evaluating the efficiency of its short- and long-term results. The variables found were a mean BMI of $39.8 \mathrm{~kg} / \mathrm{m}^{2}$ preoperatively, which decreased to $33.2 \mathrm{~kg} / \mathrm{m}^{2}$ in 1 to 6 months after the procedure and to $26 \mathrm{~kg} / \mathrm{m}^{2}$ in 1 to 2 years - there was significance at all values $(p<0.001)$. Nassif et al. $(2009)^{31}$ showed similar results with a progressive drop in BMI values, which is expected according to the literature. Also, regarding weight loss, lannelli et al. $(2011)^{20}$ stated that RYGB proved to be significantly efficient.

However, there are several limitations of BMI, which include: non-differentiation of lean and fat mass, making it difficult to assess muscular patients; do not differentiate visceral fat from subcutaneous fat; it has special tables for children and seniors ${ }^{10,26,30}$.

Kornerup, et al. (2019) 24 reported a high risk of developing micronutrient deficiencies due to extensive changes in the anatomy and physiology of the gastrointestinal tract in RYGB. In 2016, the American Society of Bariatric and Metabolic Surgery updated its nutritional guidelines aimed at bariatric patients, which described great variability in vitamin deficiencies, both pre and postoperatively. The prevalence of preoperative vitamin deficiencies of $30 \%$ for vitamin B12 and $90 \%$ for vitamin $D$ was then identified. In the present study, the mean of vitamin B12 in the analyzed periods was within the normal range, ranging from 509.8 to 639.6 . These 80 patients studied were rigorously followed up and supplemented both pre- and post-operatively. Johnson et al., (2019) ${ }^{23}$ demonstrated that postoperative deficiencies had a prevalence of up to $20 \%$ for vitamin B12 and 100\% for vitamin D. Our results showed preoperative vitamin $D$ deficiency with a mean of 26.8 .

RYGB compromises vitamin B12 absorption because almost no gastric acid remains in the gastric pouch, and as a result, food-bound release of B12 is substantially decreased. In addition, the production of intrinsic factor - a protein derived from the parietal cell necessary for the intestinal absorption of B12 - is reduced or absent in the bypassed stomach. Furthermore, B12 malabsorption is enhanced by the late introduction of pancreatic enzymes in the distal jejunum ${ }^{24,42,45}$.

As described, vitamin D deficiency is the most common preoperative deficiency, and is related to insufficient sun exposure and reduced hepatic hydroxylation ${ }^{7,15,16}$. To prevent postsurgical vitamin D deficiency, oral vitamin D supplementation of $800 \mathrm{IU}$ daily is generally recommended by the American Association of Clinical Endocrinologists and The Obesity Society ${ }^{25}$.

Recent researches with the aim of determining limit values for WHtR in different populations indicated that a cutoff point of 0.5 is the most indicated value for both genders, all ages and different populations $s^{5,27,35}$. Several studies have shown that WHtR is also a better indicator for the health of children and adolescents than other anthropometric indicators. And the cutoff point of 0.5 , which has been proposed, is close to those recommended for adults $21,29,44$.

Lima et al. (2010) ${ }^{26}$ verified the existence of a common waist-to-height ratio in male individuals, aged between 18 and 25 years, with normal fat percentages, to provide a personalized and non-generalized method of measuring waist circumference. The analysis of the sample of 174 individuals resulted to be in the age group of $21.2 \pm 2.1$ years, with height of $174.3 \pm 6.2$ $\mathrm{cm}$, with a percentage of fat of $10.8 \%$, with measurement of the abdominal circumference of $75.5 \pm 5.7 \mathrm{~cm}$, and with the waist/height ratio presenting the value of $0.43 \pm 0.033$. They concluded that there is a common relationship between the waist-to-height ratio among men aged between 18 and 25 years with a normal fat percentage of $43 \%$ of their height.

Study by Lucas et al. (2020) ${ }^{28}$, using the cutoff point of 0.5 in WHtR as a reference, evaluated the development of an equation that could determine the appropriate waist measurement of the smallest abdominal perimeter, also having as premise the $\mathrm{WHtR}$, but in a sample 454 individuals, 249 males and 205 females, between 18 and 65 years old, without the state of obesity. Regarding the percentage of height as a measure of the smallest waist circumference, the total female sample had an average of $44.2 \pm 1.1 \%$ and the male $45.3 \% \pm 1.5$. For women this percentage determined the equation of the waist-to-height ratio represented by $X=($ age +217$) / 5.875$, and for men $X=($ age+190.89) /5.2222. The " $X$ " in the equations represents the percentage of height measurement so that the individual fits into the category of adequate in relation to percentages of fat and BMI.

Our study found that the WHtR values after two years of postoperative RYGB were equivalent to 0.56 , with a reduction equivalent to $60.7 \%$ if the objective was to reach 0.45 in the study by Lucas et al. (2020) 27 .

The method of analysis of the waist/height ratio (WHtR) takes into account a perimetric measure that presents a predictive profile of the quantitative situation involving visceral fat. Therefore, the characteristics of the local subcutaneous adipose tissue may make a difference in this interpretation.

Wejustify the scoreabove 0.5 due to the anatomophysiological condition common to individuals in this obesity scenario, as in addition to hypertrophy, subcutaneous adipocyte hyperplasia is present, and ends up determining a functional residue, linked to intense weight loss. These residues are called "functional and aesthetic bodily sequelae", as mentioned by Cintra Junior et al. ${ }^{8}$

Such changes correspond to what is conventionally called dysmorphia, characterized by dermofat accumulations predominantly in the arms, breasts, abdomen and thigh, which is corroborated by the large number of patients in the RYGB postoperative period requiring submission to cosmetic surgeries, notably abdominoplasty (dermolipectomy), as mentioned by Baroudi and Moraes ${ }^{4}$.

The sum of the metabolic results presented indicates that this score is compatible with a low amount of body fat after 02 years of postoperative BYGR. Therefore, for this select group of patients, we believe that this anatomical and functional aspect should be taken into account, as a future criterion for reinterpreting the cutoff point, and promoting comparison with the post-surgical esthetic state. In this sense, we can infer that there was a greater reduction in the parameters of the waist/height ratio than the $\mathrm{BMI}$ in this period.

Although both did not manage to reach the level of normality according to their scales, when the WHtR was correlated with the BMI and the other MS markers, the superiority of the former for the identification of the cardiometabolic risk profile was evident.

\section{CONCLUSION}

The RYGB improves the metabolic syndrome and the waist/ height ratio $(\mathrm{WHtR})$ is superior to the $\mathrm{BMl}$ in the assessment of the cardiometabolic risk profile.

\section{REFERENCES}

1. Aekplakorn W, Pakpeankitwatana V, Lee CM, Woodward M, Barzi F, Yamwong S, Unkurapinun N, Sritara P. Abdominal obesity and coronary heart disease in Thai men. Obesity (Silver Spring). 2007 Apr;15(4):1036-42. doi: 10.1038/oby.2007.604. PMID: 17426340.

2. Ashwell M, Cole TJ, Dixon AK. Ratio of waist circumference to height is strong predictor of intra-abdominal fat. BMJ. 1996 Aug 31;313(7056):559-60.doi:10.1136/bmj.313.7056.559d.PMID:8790002; PMCID: PMC2351911.

3. Ashwell M, Gibson S. Comments on the article 'Optimum waist circumference-heightindicesforevaluating adultadiposity:Ananalytic review': Consideration of relationship to cardiovascular risk factors and to the public health message. Obes Rev. 2020 Sep;21(9):e13074. doi: 10.1111/obr.13074. Epub 2020 Jun 23. PMID: 32578318. 
4. Baroudi R, Moraes M. Philosophy, technical principles, selection, and indication in body contouring surgery. Aesthetic Plast Surg. 1991 Winter;15(1):1-18. doi: 10.1007/BF02273829. PMID: 1994645.

5. Bertsias G, Mammas I, Linardakis M, KafatosA. Overweightand obesity in relation to cardiovascular disease risk factors among medica students in Crete, Greece. BMC Public Health. 2003 Jan 8;3:3. doi: 10.1186/1471-2458-3-3. Epub 2003 Jan 8. PMID: 12517305; PMCID: PMC140012.

6. Buchwald,H.TheEvolution of Metabolic/Bariatric Surgery. OBESSURG 24, 1126-1135 (2014). https://doi.org/10.1007/s11695-014-1354-3

7. Burton RF. Comments on the article "Optimum waist circumference height indices for evaluating adult adiposity: An analytic review": Relationships to previous studies. Obes Rev. 2020 Mar;21(3):e12982. doi: 10.1111/obr.12982. Epub 2019 Nov 29. PMID: 31782872.

8. Cintra Junior W, Modolin MLA, Colferai DR, Rocha RI, Gemperli R. Post-bariatric body contouring surgery: analysis of complications in 180 consecutive patients. Rev Col Bras Cir. 2021 Jul 19;48:e20202638. English, Portuguese. doi: 10.1590/0100-6991e-20202638. PMID: 34287547.

9. Corcelles R, etal.Efectos del bypassgástrico sobreel riesgocardiovascular estimado. Cirugia Espanola, [s. I.], 92(1)16-22, 2014. Disponível em: https://doi.org/10.1016/j.ciresp.2013.05.014

10. Courcoulas AP, Goodpaster BH, Eagleton JK, Belle SH, Kalarchian MA, Lang W, Toledo FG, Jakicic JM. Surgical vs medical treatments for type 2 diabetes mellitus: a randomized clinical trial. JAMA Surg. 2014 Jul;149(7):707-15. doi: 10.1001/jamasurg.2014.467. PMID:24899268; PMCID: PMC4106661.

11. De-Cleva $R$, et al. Lactate can be a marker of metabolic syndrome in severe obesity? Arq Bras Cir Dig. 2021 Jun 11;34(1):e1579. doi: 10.1590/0102-672020210001e1579. PMID: 34133526; PMCID: PMC8195466.

12. Engin, A. The definition and prevalence of obesity and metabolic syndrome.In:ADVANCESINEXPERIMENTALMEDICINEANDBIOLOGY [S. I.]: Springer New York LLC, 2017. v. 960, p. 1-17. Disponível em: https://doi.org/10.1007/978-3-319-48382-5

13. Fernandes G, Santo MA, Crespo AFCB, Biancardi GB, Mota FC, Antonangelo L, de Cleva R. Early glycemic control and incretin improvement after gastric bypass: the role of oral and gastrostomy route. Surg Obes Relat Dis. 2019 Apr;15(4):595-601. doi: 10.1016/j. soard.2019.01.013. Epub 2019 Jan 31. PMID: 30803884

14. Fleischmann R, Kremer J, Cush J, Schulze-Koops H, Connell CA Bradley JD, Gruben D, Wallenstein GV, Zwillich SH, Kanik KS; ORAL Sololnvestigators. Placebo-controlled trial of tofacitinib monotherapy in rheumatoid arthritis. N Engl J Med. 2012 Aug 9;367(6):495-507. doi: 10.1056/NEJMoa1109071. PMID: 22873530

15. Fox A, Slater C, Ahmed B, Ammori BJ, Senapati S, Akhtar K, Ellison J, Summers LKM, Robinson A, New JP, Soran H, Adam S, Syed AA Vitamin D Status After Gastric Bypass or Sleeve Gastrectomy over 4 Years of Follow-up. Obes Surg. 2020 Apr;30(4):1473-1481. doi: 10.1007/s11695-019-04318-0. PMID: 31820405

16. Frayon S, Cavaloc Y, Wattelez G, Cherrier S, Lerrant Y, Ashwell M, Galy O.Potential forwaist-to-height ratio to detect overfat adolescents from a Pacific Island, even those within the normal BMI range. Obes Res Clin Pract. 2018 Jul-Aug;12(4):351-357. doi: 10.1016/j.orcp.2017.12.001. Epub 2017 Dec 15. PMID: 29254830

17. Guilbert L, Ortiz CJ, Espinosa O, Sepúlveda EM, Piña T, Joo P, Zerrweck C. Metabolic syndrome 2 years after laparoscopic gastric bypass. Int J Surg. 2018 Apr;52:264-268. doi: 10.1016/j.ijsu.2018.02.056. Epub 2018 Mar 1. PMID: 29501798.

18. Hayoz C, Hermann T, Raptis DA, Brönnimann A, Peterli R, Zuber M Comparison ofmetabolicoutcomesin patientsundergoing laparoscopic roux-en-Y gastric bypass versus sleeve gastrectomy - a systematic review and meta-analysis of randomised controlled trials. Swiss Med Wkly. 2018 Jul 5;148:w14633. doi: 10.4414/smw.2018.14633. PMID 30035801.

19. Hwaung P, Heo M, Kennedy S, Hong S, Thomas DM, Shepherd J, Heymsfield SB. Optimum waist circumference-height indices for evaluating adult adiposity: An analytic review. Obes Rev. 2020 Jan;21(1):e12947. doi: 10.1111/obr.12947. Epub 2019 Sep 10. PMID: 31507076.

20. Iannelli A, Anty R, Schneck AS, Tran A, Gugenheim J. Inflammation, insulin resistance, lipid disturbances, anthropometrics, and metabolic syndrome in morbidly obese patients: a case control study comparing laparoscopic Roux-en-Y gastric bypass and laparoscopic sleeve gastrectomy. Surgery. 2011 Mar;149(3):364-70. doi: 10.1016/j. surg.2010.08.013. Epub 2010 Oct 8. PMID: 20932542

21. Ikramuddin S, Korner J, Lee WJ, Connett JE, Inabnet WB, Billington CJ, Thomas AJ, Leslie DB, Chong K, Jeffery RW, Ahmed L, Vella A, Chuang LM, Bessler M, Sarr MG, Swain JM, Laqua P, Jensen MD, Bantle JP. Roux-en-Y gastric bypass vs intensive medical management for the control of type 2 diabetes, hypertension, and hyperlipidemia: the Diabetes Surgery Study randomized clinical trial. JAMA. 2013 Jun 5;309(21):2240-9. doi: 10.1001/jama.2013.5835. PMID: 23736733 PMCID: PMC3954742.
22. Jensen MD, et al; American College of Cardiology/American Heart Association Task Force on Practice Guidelines; Obesity Society. 2013 AHA/ACC/TOS guideline for the management of overweight and obesity in adults: a report of the American College of Cardiology/ American Heart Association Task Force on Practice Guidelines and The Obesity Society. Circulation. 2014 Jun 24;129(25 Suppl 2):S10238. doi: 10.1161/01.cir.0000437739.71477.ee. Epub 2013 Nov 12. Erratum in: Circulation. 2014 Jun 24;129(25 Suppl 2):S139-40. PMID: 24222017; PMCID: PMC5819889.

23. Johnson LM, Ikramuddin S, Leslie DB, Slusarek B, Killeen AA. Analysis of vitamin levels and deficiencies in bariatric surgery patients: a singleinstitutional analysis. Surg Obes Relat Dis. 2019 Jul;15(7):1146-1152. doi:10.1016/j.soard.2019.04.028. Epub2019 May 2. PMID: 31202681.

24. Kornerup LS, Hvas CL, Abild CB, Richelsen B, Nexo E. Early changes in vitamin B12 uptake and biomarker status following Roux-en-Y gastric bypass and sleeve gastrectomy. Clin Nutr. 2019 Apr;38(2):906-911. doi: 10.1016/j.clnu.2018.02.007. Epub 2018 Feb 15. PMID: 29506877.

25. Li Z, Zhou X, Fu W. Vitamin D supplementation for the prevention of vitamin $D$ deficiency after bariatric surgery: a systematic review and meta-analysis. Eur J Clin Nutr. 2018 Aug;72(8):1061-1070. doi: 10.1038/s41430-017-0059-9. Epub 2017 Dec 29. PMID: 29288249.

26. Lima WC, et al. Análise da relação entre a estatura e o perímetro abdominal em indivíduos portadores de percentuais normais de gordura. ABCD. Arquivos Brasileiros de Cirurgia Digestiva (São Paulo) [online]. 2010, v. 23, n. 1 [Acessado 25 Outubro 2021] , pp. 24-28. Disponívelem: <https://doi.org/10.1590/S0102-67202010000100007> Epub 22 Jun 2010. ISSN 2317-6326. https://doi.org/10.1590/S010267202010000100007

27. Lin WY, Lee LT, Chen CY, Lo H, Hsia HH, Liu IL, Lin RS, Shau WY, Huang KC. Optimal cut-off values for obesity: using simple anthropometric indices to predict cardiovascular risk factors in Taiwan. Int J Obes Relat Metab Disord. 2002 Sep;26(9):1232-8. doi: 10.1038/sj.ijo.0802040. PMID: 12187401.

28. Lucas RWDC, Nassif PAN, Tabushi Fl, Nassif DSB, Ariede BL, Brites Neto J, Malafaia O. Can stature, abdominal perimeter and bmi index predict possible cardiometabolic risks in future obesity? Arq Bras Cir Dig.2020Nov20;33(2):e1529.doi:10.1590/0102-672020200002e1529. PMID: 33237167; PMCID: PMC7682149.

29. McCarthy HD, Ashwell M. A study of central fatness using waistto-height ratios in UK children and adolescents over two decades supports the simple message--'keep your waist circumference to less than half your height'. Int J Obes (Lond). 2006 Jun;30(6):988-92. doi: 10.1038/sj.ijo.0803226. PMID: 16432546.

30. Nassif PA, Malafaia O, Ribas-Filho JM, Czeczko NG, Garcia RF, Ariede $\mathrm{BL}$. Vertical gastrectomy and gastric bypass in Roux-en-Y induce postoperative gastroesophageal reflux disease? Arq Bras Cir Dig. 2014;27 Suppl 1(Suppl 1):63-8.doi:10.1590/s0102-6720201400s100016. PMID: 25409970; PMCID: PMC4743523.

31. Nassif PAN, et al. Alterações nos parâmetros pré e pós-operatórios de pacientes com síndrome metabólica, submetidos a Bypass gastrointestinal em Y de Roux. ABCD. Arquivos Brasileiros de Cirurgia Digestiva (São Paulo), [s. I.], v. 22, n. 3, p. 165-170, 2009. Disponível em: https://doi.org/10.1590/s0102-67202009000300006

32. Neeland IJ, Ross R, Després JP, Matsuzawa Y, Yamashita S, Shai I, Seidell J, Magni P, Santos RD, Arsenault B, Cuevas A, Hu FB, Griffin B, Zambon A, Barter P, Fruchart JC, Eckel RH; International Atherosclerosis Society; International Chair on Cardiometabolic Risk Working Group on Visceral Obesity. Visceral and ectopic fat, atherosclerosis, and cardiometabolic disease: a position statement Lancet Diabetes Endocrinol. 2019 Sep;7(9):715-725. doi: 10.1016/ S2213-8587(19)30084-1. Epub 2019 Jul 10. PMID: 31301983.

33. Nevill AM, Duncan MJ, Lahart IM, Sandercock GR. Scaling waist girth for differences in body size reveals a new improved index associated with cardiometabolic risk. Scand J Med Sci Sports. 2017 Nov:27(11):1470-1476. doi: 10.1111/sms.12780. Epub 2016 Oct 10 PMID: 27726187

34. Oliveira SC, Neves JS, Souteiro P, Pedro J, Magalhães D, Guerreiro V, Bettencourt-Silva R, Costa MM, Varela A, Barroso I, Freitas P. AMTCO Group, Carvalho D. Impact of Bariatric Surgery on Long-term Cardiovascular Risk: Comparative Effectiveness of Different Surgical Procedures. Obes Surg.2020Feb;30(2):673-680. doi:10.1007/s11695019-04237-0. PMID: 31749108.

35. Pitanga FJG, Lessa I. Razão cintura-estatura como discriminador do risco coronariano de adultos, Rev. Assoc. Med. Bras, 52(3):157-61. 2006.

36. Prentice AM, Jebb SA. Beyond body mass index. Obes Rev. 2001 Aug;2(3):141-7.doi:10.1046/j.1467-789x.2001.00031.x.PMID:12120099.

37. Ross R, Neeland IJ, Yamashita S, Shai I, Seidell J, Magni P, Santos RD, Arsenault B, Cuevas A, Hu FB, Griffin BA, Zambon A, Barter P, Fruchart JC, Eckel RH, Matsuzawa Y, Després JP. Waist circumference as a vital sign in clinical practice: a Consensus Statement from the IAS and ICCR Working Group on Visceral Obesity. Nat Rev Endocrinol. 2020 Mar;16(3):177-189. doi: 10.1038/s41574-019-0310-7. Epub 2020 Feb 4. PMID: 32020062; PMCID: PMC7027970. 
38. Ruzzon A, Nassif PAN, Prigol L, Buzo L, Wendler G, WendlerE, Wendler IBT, Ruzzon I, Goveia CHM, Gonçalves LAP. Roux-in-Y gastrojejunal bypass: which anesthetic technique has best results? Arq Bras Cir Dig. 2021 May 14;34(1):e1530. doi: 10.1590/0102-672020200002e1530. PMID: 34008703; PMCID: PMC8121063.

39. Said S, Mukherjee D, Whayne TF. Interrelationships with Metabolic Syndrome, Obesity and Cardiovascular Risk. Curr Vasc Pharmacol. 2016;14(5):415-425. doi: 10.2174/1570161114666160722121615. PMID: 27456105.

40. Samson SL, Garber AJ. Metabolic syndrome. Endocrinol Metab Clin North Am. 2014 Mar;43(1):1-23. doi: 10.1016/j.ecl.2013.09.009. PMID: 24582089.

41. Schlottmann F, Galvarini MM, Dreifuss NH, Laxague F, Buxhoeveden R, Gorodner V. Metabolic Effects of Bariatric Surgery. J LaparoendosC AdvSurg Tech A. 2018Aug;28(8):944-948. doi:10.1089/lap.2018.0394. Epub 2018 Jul 13. PMID: 30004821.

42. Sjöström L, Peltonen $M$, Jacobson $P$, Sjöström CD, Karason K, Wedel H, Ahlin S, Anveden Å, Bengtsson C, Bergmark G, Bouchard C, Carlsson

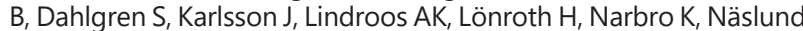
I, Olbers T, Svensson PA, Carlsson LM. Bariatric surgery and long-term cardiovascular events. JAMA. 2012 Jan 4;307(1):56-65. doi: 10.1001/ jama.2011.1914. PMID: 22215166.
43. Varaschim M, Nassif PA, Moreira LB, do Nascimento MM, Vieira GM, Garcia RF, Sue KM, Cruz MA. Changes in clinical and laboratory parameters in obese patients with type 2 diabetes mellitus submitted to Roux-en-y gastrojejunal bypass without ring. Rev Col Bras Cir. 2012 May-Jun;39(3):178-82. English, Portuguese. PMID: 22836564.

44. Weili Y, He B, Yao H, Dai J, Cui J, Ge D, Zheng Y, Li L, Guo Y, Xiao K, Fu X, Ma D. Waist-to-height ratio is an accurate and easier index for evaluating obesity in children and adolescents. Obesity (Silver Spring). 2007 Mar;15(3):748-52. doi: 10.1038/oby.2007.601. PMID: 17372326.

45. WendlerE, etal. Abreviarjejum pré-operatório eintroduziralimentação precoce auxiliam na recuperação após bypass gastrojejunal? ABCD 2021; 34(2):e1606 